\title{
Serbien skuer mod EU, men belastes konstant af fortiden
}

\section{Vibeke Sperling}

\section{Serbien strammer sin udenrigspolitik med uden- rigsministerens udtalelse, at hvis Serbien skal væl- ge imellem Kosovo og EU, så bliver det ikke EU}

Illusionen om at det blot er et spørgsmål om tid, før Serbien erkender, at Kosovo er tabt for evigt, fik i begyndelsen af marts et skud for boven.

Landets udenrigsminister Vuk Jeremic hævede nemlig under et besøg i Budapest indsatsen for at bevare Kosovo som serbisk til hidtil usete højder, da han sagde: "Enhver, som tror, at Serbien, hvis det skulle vælge imellem EU og Kosovo, ville vælge EU, tager fejl. Det vil aldrig ske”. Og han tilføjede, at det vil være forkert "at presse Serbien til at vælge imellem de to, for vi har ikke noget valg".

Konflikten om Kosovos status skal løses gennem 'kompromis', fastholder Jeremic og lægger op til en ny runde $\mathrm{FN}$-formidlede forhandlinger, selv om halvandet års forhandlinger af den slags tidligere endte uden resultat. Serbien er parat til at diskutere enhver form for løsning, "bortset fra den ensidige uafhængighedserklæring".

Hidtil har Jeremic henholdt sig til, at Serbien ikke behøver at vælge. Og så længe fem EU-lande nægter at anerkende Kosovos selvstændighed, har han formelt set ret. Men den dominerende holdning i EU er nu, at de genstridige EU-lande må rette ind og Serbien erkende realiteterne, at den eneste tænkelige genforening med Kosovo er som to suveræne medlemmer af EU.

I december sidste år afleverede Serbien sin formelle ansøgning om EU-medlemskab, selv om Bruxelles havde tilkendegivet, at det var for tidligt. Men Serbien ventes snart at kunne opnå en Stabiliserings- og Associeringsaftale (SAA), der jo som bekendt ses som det første skridt til medlemskab. Den største forhindring er ud fra en overfladisk betragtning ikke konflikten om Koso- 
vos status, men Serbiens fortsat manglende udlevering af de bosniske serberes militære øverstkommanderende, Ratko Mladic, til krigsforbryderdomstolen i Haag.

"Vi er bevidste om vanskelighederne i forbindelsen med processen i EU, men vi har ingen tid at spilde. Vi kan ikke tillade endnu en afbrydelse i associeringsprocessen", sagde Jeremic.

\section{Ros og ris til Jeremic}

Vojislav Kostunica, tidligere præsident og ministerpræsident og leder af Serbiens Demokratiske Parti (DSS), hyldede Jeremic for at bringe politikken over for Kosovo tilbage til hans partis standpunkt: at Kosovo ikke sælges for EU-medlemskab.

Det er da også blevet svært at se forskel på Jeremic og Kostunica, der ikke ville drøfte EU-medlemskab, hvis EU ikke accepterer, at Kosovo er serbisk område.

Cedomir Jovanovic, leder af Liberaldemokraterne, det eneste serbiske parti som støtter Kosovos selvstændighed, kritiserede derimod Jeremic for at bringe Serbiens muligheder for EU-medlemskab i fare og vanskeliggøre et normalt liv for serberne: "Kun en dag efter den franske udenrigsministers besøg, hvor konklusionen var, at Kosovo er et problem og en byrde fra fortiden, har Jeremic ikke ret til at binde vore hænder for fremtiden og sætte be- tingelser for vor indtræden i EU ved at skabe irriterende dilemmaer og en atmosfære, hvor der ikke kan ske noget positivt for Serbien". Jovanovic advarede imod "skadelige konsekvenser internt i Serbien og for de bestræbelser, som Serbien har gjort for europæisk integration, for Jeremic har sendt den besked til samfundet, at Serbien måske vil bevare sine vaner fra fortiden og ikke ændre noget som helst i sin holdning til fortidens begivenheder".

Cedomir Jovanovic mener, at Serbien for sin egen fremtids skyld må erkende, at Kosovo er tabt for evigt på grund af Slobodan Milosevic' forbrydelser imod Kosovos albanere.

Serbiens præsident Boris Tadic overbragte i december sidste år sit lands ansøgning om medlemskab til EU's daværende svenske formandsskab.

Tadic har tidligere sagt, at Serbien ville vente med at ansøge, til der var opbakning fra hele EU, men besluttede i december at de seneste måneders 'momentum' skulle udnyttes, herunder positive vurderinger fra Bruxelles af landets tilnærmelse til EU. Holland og Storbritannien talte mest ihærdigt for, at Serbiens ansøgning måtte vente.

Den svenske statsminister Fredrik Reinfeldt sagde: "De største udfordringer for Serbien er gennemførelse af reformer og at finde og arrestere de eftersøgte krigsforbrydere".

Sverige udenrigsminister, Carl Bildt, kaldte det det rette tidspunkt 
for Serbiens ansøgning og "et meget vigtigt led i et helt nyt opsving for processen til EU-integration for alle landene i Vestbalkan". Med Irlands ja til Lissabon-traktaten blev det ifølge Bildt muligt at bringe Vestbalkan tilbage på EU's dagsorden. Men som Daniel Korski beskriver i dette nummer af Udenrigs, dominerer trætheden i EU over for Vestbalkan.

\section{Stor folkelig støtte}

Meningsmålinger viser overvældende støtte med op mod 70 procent af serberne for EU-medlemskab, men der er samtidig flertal imod at pågribe og udlevere Ratko Mladic til Haag. Denne modsætning tilskrives den udbredte opfattelse blandt serbere, at domstolen er partisk imod dem. For almindelige serbere har det intet at gøre med deres ønske om at komme ind i EU's varme.

Blandt fremskridtene for Serbien er, at landets borgere lige som borgere i Montenegro og Makedonien lige før årsskiftet opnåede delvis visumfrihed til EU, samt at en frihandelsaftale med EU blev erklæret klar til at blive sat i værk. Den er del af Stabiliserings- og Associeringsaftalen (SAA), som stadig er blokeret, fordi Holland modsætter sig dens ikrafttræden, før Mladic er udleveret.

Chefanklageren for krigsforbryderdomstolen i Haag udtalte i en ny rapport inden årsskiftet, at Serbien har gjort store fremskridt i samar- bejdet med Haag. Serge Brammertz understregede dog i rapporten til FN's Sikkerhedsråd, at Serbien må pågribe Mladic, der blandt andet er anklaget for massakren på op mod 8.000 serbiske mænd og drenge i Srebrenica i Bosnien i 1995. Udleveringskrav gælder også serberen Goran Hadzic, der er anklaget for krigsforbrydelser i provinsen Krajina i Kroatien. Han spiller dog ingen blokerende rolle som Mladic for Serbiens integration i EU.

Det er en stor sten på EU-vejen, at Mladic stadig er på fri fod, selv om Serbien uendelig mange gange har proklameret, at pågribelse af ham var nær. Der kommer næppe for alvor gang i optagelsesforhandlinger for Serbien, før Mladic er i Haag. Men Holland har dog blødt op på sin position og udtalt, at det ikke vil modsætte sig, at processen sættes i gang.

Frankrigs udenrigsminister Bernard Kouchner sagde i den forbindelse: "Vi må overvinde Hollands opposition. De har blokeret i umindelige tider”. Og Beograd sætter nu sin lid til næste rapport fra Brammertz, som ventes i juni.

\section{Skrappe betingelser}

Kouchner gjorde på sin side klart under sit seneste besøg i Beograd, at det også haster med, at Serbien 'normaliserer' forholdet til alle naboer, herunder ikke mindst Kosovo. Men under alle omstændigheder 
mener kommentatorer i både Beograd og Bruxelles, at der vil gå mange år, før EU's døre åbnes for Serbien.

Mark Almond, britisk historieprofessor, siger til Bloomberg.com, at betingelserne for Serbien formentlig bliver usædvanlig skrappe: "Det er meget let for EU at sige 'I har ikke fanget Mladic endnu', når der opstår problemer".

Fra årsskiftet overtog Spanien EUformandskabet. Det stillede Serbien store forhåbninger til, fordi Spanien er kæmpen blandt de fem EU-lande, som endnu ikke har anerkendt Kosovo. Spanien tilkendegav, at det vil bruge formandskabet til at fremme Serbiens interesser, både når det gælder EU-medlemskab og når det gælder Kosovo.

Med udnævnelsen af en præsident og en udenrigsrepræsentant for EU, ventes det imidlertid at blive begrænset, hvad skiftende formandskaber får af udenrigspolitisk indflydelse.

Om Kosovo sagde Tadic i Stockholm: "Vi vil løse den udfordring, men det betyder ikke, at vi nogensinde vil anerkende Kosovos selvstændighed".

Reinfeldt tog ikke den udfordring op, men sagde, at Serbiens ansøgning i sig selv "er en ny begyndelse for Serbien, der afspejler regeringens stærke beslutsomhed og den udbredte folkelige støtte til medlemskab i Serbien".

For Serbien er EU-ansøgningen dog endnu snarere en bøn til EU end noget, der kan give umiddelbare resultater.

\section{Neddæmper forventninger}

"Dette er starten på en ny fase med dybtgående og pinefulde reformer", sagde Boris Tadic i et forsøg på at dæmpe serbernes store forventninger.

Men, som den serbiske radio- og tv-station B92 understregede, "giver det håb, at borgerne er så ivrige efter integration i EU, på trods af, at de for ikke længe siden blev bombet af flere af de lande, som de nu ønsker at komme i union med”. B92 henviste til Nato's bombardementer i 1999 for at drive de serbiske styrker ud af Kosovo.

De meget EU-ivrige serbere nægter at opgive Kosovo, men meningsmålinger har faktisk vist, at hvis valget står imellem Kosovo og EU, vil flertallet vælge det sidste. Om udenrigsminister Vuk Jeremics udtalelser vil ændre det, står tilbage at se.

Ud over barske reformer på vejen til EU må serberne, det tidligere Jugoslaviens største folk, overvinde arven efter den tidligere præsident, Slobodan Milosevic, der blev afsat af en folkelig opstand i 2000 efter et årtis brutalt styre.

Milosevics nationalistiske hysteri, som var en af hovedårsagerne til, at Jugoslavien blev flået i stykker, hænger stadig som en skygge over Serbien, især i den udbredte opfattelse 
blandt serberne, at de kun er ofre for anti-serbiske følelser.

Milosevic, der udnyttede magttomrummet efter Titos død i 1980 til at oppiske had imod kosovarerne, døde i 2006, kort før afslutningen af retssagen imod ham. Den serbiske forsvarsadvokat Mirko Barovic siger: "En dom over Milosevic kunne have hjulpet serberne med at bearbejde fortiden".

\section{Parat til Europa}

$\mathrm{Nu}$ lover serberne at tilpasse sig moderne europæiske værdier. "Vi bekræfter nu for første gang på skrift, at vi er parate til at indoptage alle europæiske værdier", sagde Milica Delevic, leder af Serbiens Kontor for Europæisk Integration, til Beogradavisen Politika i forbindelse med EUansøgningen.

Blandt stenene på vejen til EU er også EU's krav om regional integration som forudsætning for EU-medlemskab. Serbien har stadig lang vej igen til forsoning med naboerne. Kun forholdet mellem Makedonien og Serbien er overvejende afslappet, da de to lande ikke var i krig med hinanden.

Kroatien søger at lægge kulturel afstand til Serbien ved for eksempel at synkronisere serbiske film til kroatisk, selv om det er to dialekter af samme sprog. I Bosnien anklager bosniakker (muslimer) og kroater Serbien for at støtte løsrivelse af den serbiske del, Republika Srpska. Der- for har Bosnien trukket anerkendelse af Kosovo ud, da landets serbere mener, at de har lige så stor ret til selvstændighed som Kosovos albanere.

Et prisbelønnet forsoningsprojekt var sidste år udgivelse af en fælles bog, skrevet af historikere fra Serbien, Montenegro og Bosnien. Men historiebogen standser før krigene i 1990'erne, da forfatterne måtte sande, at "det er for tidligt at skabe en fælles forståelse af krigene".

Der står primært krigsforbrydersager og grænsestridigheder i vejen for forsoning. Hvad angår det sidste udtalte det serbiske udenrigsministerium tidligere $\mathrm{i}$ år, at der er 'stor velvilje' i både Zagreb og Beograd, når det gælder løsning af konflikten om grænsen ved floden Donau, som en fælles kommission har fået til opgave at løse.

"Jeg håber, at kommissionen vil finde en løsning, der kan forhindre international indblanding", sagde det serbiske udenrigsministeriums politiske direktør, Borko Stefanovic, til det statsejede nyhedsbureau Tanjug.

Helt så let bliver det ikke, da Serbien mener, at grænsen skal gå i Donaus løb, mens Kroatien gør krav på områder på den serbiske side af floden.

Lige som Kroatiens EU-ansøgning har været belastet af grænsestridigheder med EU-landet Slovenien, frygter kroatiske kommentatorer, at grænsekonflikter med Serbien og 
Bosnien-Hercegovina vil betyde yderligere udskydelse.

Kroatien vil ikke komme i EU før i 2013 på grund af grænsekonflikten med Serbien, skrev det kroatiske ugemagasin Globus i marts. Ifølge Globus har Kroatien fået besked fra Bruxelles om, at landet kan tilsluttes EU i 2013 sammen med Island, "men kun hvis det inden 2011 løser de åbne spørgsmål om dets grænse med Serbien og Bosnien-Hercegovina”.

\section{Krigens spøgelse}

Og spøgelset fra den bosniske krig blev vækket igen, da den bosniske vicepræsident under krigen, Ejup Ganic, blev arresteret i Heathrow lufthavn 1. marts efter Serbiens krav om hans udlevering.

Den samtidige genoptagelse af sagen imod Radovan Karadzic, de bosniske serberes leder under krigen, har ført til anklager imod Serbien for at udnytte sagen imod muslimen Ganic til støtte for Karadzic. Men hertil må siges, at Serbien selv udleverede Karadzic og har erklæret at tiden for beskyttelse af krigsforbryderanklagede var forbi.

Det kan tage måneder for en britisk domstol at tage stilling til, om Ganic skal udleveres til en krigsforbryderdomstol i Beograd.

Retssagen imod Karadzic og arrestationen af Ganic pisker til den bitre debat imellem serbere og bosniakker (Bosniens muslimer) om, hvad der egentlig skete i Sarajevo i maj 1992, da krigen startede.

Ibrahim Prohic, kommentator ved Sarajevo dagbladet Oslobodjenje sagde til Radio Free Europe, at sammenfaldet mellem sagen imod Karadzic og arrestationen af Ganic ikke er noget tilfælde. "Der er meget troværdige indikationer på, at nogen har styret det sådan. Dem, som startede det onde, har over de sidste 20 år vist en forbavsende dygtighed". Prohic forudså, at sagen vil skade det i forvejen konfliktfyldte forhold imellem Serbien og Bosnien.

Beograd begrunder sit udleveringskrav med, at Ganic var ansvarlig for 40 serberes død den 3. maj 1992. De var soldater i Jugoslaviens National Hær (JNA). Ifølge Beograd krænkede de muslimske styrker en indgået våbenhvile, da de åbnede ild imod en JNA-kolonne. Bosniens præsident Alija Izetbegovic var dagen før blevet pågrebet af JNA i Sarajevos lufthavn, så Ganic var ansvarlig som fungerende præsident.

Anklagerne imod Ganic går til kernen af Karadzics forsvar. Han fortalte under genåbningen af sagen, at serberne var de første ofre for vold i Bosnien, nemlig 3. maj 1992. Karadzic hævdede, at serberne kun forsvarede sig imod muslimske fundamentalister, der ville skabe en muslimsk stat i Bosnien. Og både Beograd og de bosniske serbere ser Ganic som en af de islamiske fundamentalister.

Hvorom alting er, så bliver Ganics 
eventuelle ansvar for drabet på 40 serbiske soldater i begyndelsen af krigen søgt sidestillet med alle de rædsler, som Karadzic er anklaget for.

Rasende kommentarer er siden væltet ind på serbiske og internationale netsider. En bosnisk serber, der nu bor i USA, skriver til Radio Free Europes netside: "Det er på høje tid, at Ganic stilles til ansvar for sine handlinger. Angrebet på en kolonne af unge og ubeskyttede soldater er af største betydning. Tænk på om din søn var med”. En bosnisk muslim, der kalder sig Bosanac, svarede: "Hvilke ofre? De holdt Sarajevo belejret med artilleri og snigskytter, og nu er de pludselig blevet ofre? Krigens politik og propagandaen fortsætter".

En bosnisk kvinde skældte fra Beograd ud på den megen medieopmærksomhed om Ganic: "Ingen følger retssagen imod Karadzic, men alle følger med i, hvor Ganic er".

I Republika Srpska har adskillige fortalt udenlandske journalister, der har spurgt til Ganic-sagen, at han kan sammenlignes med Karadzic og at det er lige så vigtigt at retsforfølge Ganic som at drage Karadzic til ansvar.

Anto Nobilo, en kroatisk advokat, der har forsvaret den bosnisk-kroatiske general Tihomir Blaskic i Haag, følte sig overbevist om, at Serbiens udleveringskrav imod Ganic var led i en velkoordineret aktion for at sidestille en bosnisk muslims forbrydelser med en bosnisk serbers.

"Serbien har en sammenhængende politik og strategi. Om vi kan lide det eller ej, så må vi acceptere det. Det er en gennemtænkt politik, som de ikke opgiver".

Bosnisk-muslimske eksilgrupper har deltaget i den ophedede debat og krævet, at Bosnien tilbagekalder sin nyligt udnævnte ambassadør til Beograd.

Flere britiske medier betvivler, at Ganic nogensinde vil blive udleveret til Serbien, da der er grund til at tro, at han ikke får en fair behandling, når serberne er så opsatte på at sammenligne Ejup Ganic med den serber der er sigtet for de værste krigsforbrydelser.

Under alle omstændigheder viser de ophidsede følelser at spæde skridt til forsoning imellem Serbien og naboerne hurtigt ødelægges af krigens spøgelser, som lever og har det alt for godt.

Vibeke Sperling er journalist på Politiken og redaktør af Udenrigs. 